\title{
DEFINITION OF NATIONAL RESILIENCE IN UKRAINE IN THE SCIENTIFIC OPINION OF DOMESTIC RESEARCHERS (PART 1)
}

\author{
Olena L. Korolchuk ${ }^{1}$ \\ Maryna M. Bilynska ${ }^{2}$ \\ Sergii Y. Mokretsov ${ }^{3}$ \\ Larysa A. Gaievska ${ }^{4}$ \\ Yevhenii A. Kulhinskyi ${ }^{5}$
}

\begin{abstract}
The urgency and importance of this issue are due to the fact that the government, public administration, civil society are increasingly emphasizing the need to update strategies to ensure stability, resilience of the nation and the country to modern risks and disasters that have become complex, hybrid, less predictable. The purpose of this article is to highlight the issues of formation and development of national resilience in modern scientific thought in Ukraine and the search for a relevant definition of this concept. The leading approach to the
\end{abstract}

study of this issue was inductive thematic analysis, which revealed the achievements of domestic science, identified major trends in the views of experts on the problem, explored the relevance and level of knowledge of the problem of determining national resilience in Ukraine. The article reveals that today there is still no generalized, agreed definition of national resilience in Ukraine; the relevance of this issue in the light of the impact of modern risks and threats is disclosed; the main publications on this topic are found to

\footnotetext{
${ }^{1}$ Department of Social and Humanitarian Policy, National Academy for Public Administration under the President of Ukraine, Ezhen Pottier Str., 20, Kyiv, 03057, Ukraine; Department of Health Systems Management, Ariel University, Ramat HaGolan Str., 65, Ariel, 4077625, Israel. E-mail: o.l.korolchuk55142-7@uoel.uk

${ }^{2}$ Department of Public Administration and Public Service, National Academy for Public Administration under the President of Ukraine, Ezhen Pottier Str., 20, Kyiv, 03057, Ukraine

${ }^{3}$ Department of Social and Humanitarian Policy, National Academy for Public Administration under the President of Ukraine, Ezhen Pottier Str., 20, Kyiv, 03057, Ukraine

${ }^{4}$ Department of Social and Humanitarian Policy, National Academy for Public Administration under the President of Ukraine, Ezhen Pottier Str., 20, Kyiv, 03057, Ukraine

${ }^{5}$ Department of Prosthodontics and Orthodontics, Kyiv Medical University, Boryspilska Str., 2, Kyiv, 02099, Ukraine; Department of Social and Humanitarian Policy, National Academy for Public Administration under the President of Ukraine, Ezhen Pottier Str., 20, Kyiv, 03057, Ukraine
} 
address issues of national stability and security in various spheres of state life: public administration, sociohumanitarian, financial and economic, national security, civil society development, etc. and an author's definition of national resilience of Ukraine is provided. The materials of the article have practical value for the development and implementation of a strategy for the development of national resilience in Ukraine in order to prevent and overcome today's complex risks and threats and provide a fruitful environment for the well-being of descendants. Also, it can be used by scientists, practitioners, government institutions and public administration bodies, representatives of civil society for the development and implementation of this concept in Ukraine.

Keywords: national resilience, national stability, defense sphere safety, threats, public administration, civil society development.

\section{INTRODUCTION}

We live in a world of major geopolitical shifts and life-changing technological innovations and yet there is a need to acknowledge that new and looming challenges are looming. From the rise of nationalism, to increased demands for privacy, following widespread data leaks; from balancing growing human needs with planetary and environmental limits, to the impacts of sophisticated automation on people's lives (Kharytonova, 2008). The list is long, and there is undoubtedly space for all stakeholders - policy-makers, civil society, corporations, media, academia to take responsible action that brings about a stable, sustainable and peaceful world (Magnoni, 2018).

Today, humanity is facing global challenges caused by economic, social and political crises, the inability of international organizations to ensure global peace, various natural and manmade disasters, and the spread of deadly viruses and bacteria (Shkuropadska, 2017). Globalization is often associated with the spread of poverty, destruction of cultural identity and deterioration of the environment, the optimization of the renewed architecture of international relations; hybridization of stressors, unprecedented combinations of them leading to the rise of turbulence and unpredictability of the impact and consequences of their occurrence 
(Marhasova, 2014). The growing level of global threats, risks, challenges, dangers (hereinafter - stressors) stimulates the need for societies and countries to seek new ways to protect people from natural and anthropogenic disasters that can ensure the stability of life processes in crisis and future development. It is not just about adaptation, but about innovation, creativity and a real change of imperatives to provide abilities, opportunities, resources to tackle the big challenges of our time (Surmin, 2019). Therefore, issues of national resilience (hereinafter - NR) are becoming increasingly important (Chuprii, 2019; Protasenko, 2019; Shypilova, 2019).

The events of the last decade show that the comprehensive processes of globalization, informatization, digitalization, which have permeated all spheres of life (Kyrylov, 2016) of countries, societies, nations, generate ambiguous trends and constant struggle for opportunities to resist and develop. This has some positive consequences, for example, the strengthening of integration processes at all levels, the effects of scaling, the rapid spread of innovation in different countries, etc. There are important "advantages" of foreign economic nature, such as freedom of choice, freedom of thought (Lipkan, 2008; Chervinskyi and Shutysh, 2014) and so on. On the other hand, the range and scale of new stressors are expanding: the emergence of new challenges, such as the development of technologies of the sixth technological process, exacerbation of environmental and social problems, changes in the international movement of capital and more. This requires finding modern effective ways to solve new problems based on the country's development strategies (Masten, 2017; Sokolova et al., 2018). A clear characteristic of modern stressors is the uncertainty that can ever worsen current trends (Havryliuk, 2014) and provoke unknown consequences.

Humanity is also facing a global health crisis that is spreading human suffering, infecting the global economy and turning people's lives upside down. Current responses at the country level are not able to address the global scale and complexity of the crisis. "This is, above all, a human crisis that calls for solidarity" - said Antonio Guterres, the ninth Secretary-General of the United Nations. This moment of unprecedented situation, when normal rules and usual tools no longer work, requires coordinated, decisive and innovative 
GËNERO E

INTERDISCIPLINARIDADE
Vol n 02 | nº 01 | ISSN: 2675-7451

https://www.periodicojs.com.br/index.php/gei/index political actions from the world's leading economies. The creativity of the response must match the unique nature of the crisis - and the magnitude of the response must match its scale (Guterres, 2020).

It is possible to ensure adequate countermeasures for today's hybrid threats only under the condition of cooperation among state institutions, civil society organizations, business, media, IT sector and all other engaged actors, because integrated stressors require joint efforts. Therefore, for the purpose of the application of measures to present joint answers, the creation of an evidence-based concept and strategy that is able to cope with this task is required. Civil society will require governments to ensure individual and collective safety, well-being, but the stagnant revenue growth, distrust of the government, the polarization of society and a growing list of urgent environmental problems, will be the agenda in the activities of public servants. Therefore, in formulating development strategies of Ukraine, as well as any state, and analyzing possible scenarios of global landscape development, researchers claim that all the positive opportunities of mankind can be realized only through the creation of a resilient state through resilient public administration (Kuibida et al., 2018; Bilynska and Kavylin, 2019). It can be achieved through the introduction of strategic planning, technologies and processes that will ensure resilience during crises (Global trends..., 2017).

NR's strategy is recognized as a new, modern, effective strategy in the world, which, in addition to creating fruitful conditions for life and development, provides a reliable healthy environment and many opportunities for quality life for future generations (The National Security..., 2020). It is this path that we see as the most productive, effective and promising for the development of states and nations for the next decades. Most countries have already recognized this path of development. It is only gaining momentum in Ukraine, and is a controversial issue for scientific discussions aiming to form an authentic for Ukraine, scientifically sound basis for the introduction of NR in all state policies.

\section{MATERIALS METHODS}

AND 
The

theoretical

and

methodological basis of our study are the fundamental and modern provisions of the theory, the work of domestic scientists and practitioners, specialists of scientific institutions in the field of management and administration and more. Also, the considered developments on formation of national resilience and its development in various spheres of activity of the state and public relations and interactions which also influence maintenance of development of a democratic society in Ukraine, provide quality and efficiency of functioning both the country as a whole, and long productive activity of people, nations. To achieve this goal, a set of methods and techniques of scientific knowledge is used in the work. The method of logical generalization is used to theoretically substantiate the importance of the tasks and clarify the key concepts of the study. Using the methodology of system analysis and synthesis, a study of approaches to the formulation of national resilience was conducted and its important role in the processes of development and livelihood of countries and nations was determined. Methods of theoretical generalization, grouping and comparison were used to study the components of national resilience and national conditions of development used today in modern scientific sources in Ukraine, the main of which were the use of national stability and national security in modern conditions of risks and threats.

In the process of conducting this study, such theoretical methods were used: analysis, synthesis, concretization, generalization, analogy, modeling. The leading approach to the study of this issue was inductive thematic analysis, which revealed the achievements of domestic science, identified major trends in the views of experts on the problem, explored the relevance and level of study of the problem of determining national resilience in Ukraine. The purpose of this article is to identify the diversity of national academic opinion on the concept of national resilience to identify gaps, vectors and opportunities for further research on this issue. The review of the literature allows to get a holistic view on diverse and interdisciplinary points of view in order to form a personal opinion on the concept of national resilience, which is a necessary step and an integral part of any study. Additionally, it helps define the conceptual content and stimulates theory 
GÉNERO E

INTERDISCIPLINARIDADE
Vol n 02 | nº 01 | ISSN: 2675-7451

https://www.periodicojs.com.br/index.php/gei/index development on this issue. The research discussed in this article is based on theoretical assumptions, as it allows conclusions to be drawn from the revised literature.

Scientific publications and reports that are freely available in scientific databases of Ukraine were studied. The search for scientific literature was carried out during November-May two thousand nineteen and two thousand twenties in accordance with the standard items of reports for systematic reviews. The review included publications on the development and formation of national resilience, national stability and security in various spheres of life of the country and society. Also, in the framework of the study to ensure understanding of the importance of considering this topic, publications were considered to identify important components of the conditions of modern development of Ukraine, such as VUKA-world, sustainability, major trends in the study of threats and risks to the country and its population. publications of recent years by domestic scientists. The classification context was created in the areas of studying the definition of the national resilience concept, identifying the elements of application that are most relevant for
Ukraine today - national security, public administration, socio-humanitarian sphere and civil society. Since we were limited to one article, it was decided to publish the collected materials in two parts.

\section{RESULTS}

\subsection{Contemporary Stressors}

The rapid development of globalization and informatization is burdened by global problems related to anthropogenic crises - political, economic and social, the inability of international organizations to ensure global peace, natural and man-made disasters - fires, floods, tsunamis, earthquakes, the spread of new deadly viruses and bacteria, etc. Modern stressors of the world, daily catastrophes, natural disasters, manifestations of climate change, economic failures, social crises, cyber-attacks, hostilities, terrorist acts inflict unprecedented damage, especially affecting the most powerful potential of countries, nations people. At the same time, the number of cases of combined risks and threats that create turbulence and complex impacts, such as negative changes in climate and natural resources, burdened with risks of economic, environmental, national 
security, etc., is constantly growing. These tendencies are confirmed by the National Intelligence Council USA (Global trends..., 2017), the main global trends of key influences on human development are:

1. The life of the rich will be longer, the life of the poor will be shorter. The working-age population is declining in developed countries. However, it is growing in poorer countries, stimulating economic growth, employment and urbanization, but not increasing the welfare of the population, thus leading to increased migration. Therefore, lifelong learning for socialization and prolonged economic activity will be critical for both developed and developing countries.

2. The fundamentals of the world economy will shift - weak economic growth is projected, hence powerful economies of the world will experience labor shortages along with declining productivity with a significant debt burden, declining demand and the uncertainties of globalization.

3. Technology will accelerate progress, but it will create gaps - by stimulating change and creating new opportunities, it will force people to choose between victories, gains and losses. Automation and artificial intelligence will change industrial capacity faster than the economy can adapt to it, which will free up labor and limit the involvement of developing countries in the production process. Biotechnology, such as genome modification, will revolutionize medicine but have moral implications, and so on.

4. New ideas and identification will drive waves of exclusion (personification), and the growth of global ties amid weak economic growth will lead to tensions within and between communities and nations. The level of influence of religions will increase, which means that they will compete with the influence of state institutions. Gender issues will remain relevant: the status of women and their leadership roles will increase, but inequality will persist.

5. Public governance will become increasingly complex, and civil society (hereinafter referred to as the CS) will require governments to provide individual and collective security, prosperity, and so on. However, the slowdown in incomes, distrust towards the authorities, the polarization of society and the growing list of urgent 
environmental problems will become

special attention. Today, the critical issues to be addressed.

6. The nature of political conflicts will continue to change. The risk of conflicts will increase, terrorist attacks, lethal weapons will spread, threats of loss of statehood for politically weak states etc.

7. The focus will also be on climate change and the challenges and threats it poses to the environment and human health. The number of natural and man-made disasters and their long-term complex consequences will require the collective efforts of humanity. Extreme weather phenomena, lack of drinking water, soil erosion and, as a consequence, lack of food will lead to the destruction of human habitats, uncontrolled migration, violence and wars, outbreaks of infectious diseases epidemics, pandemics (Global trends..., 2017).

On the other hand, it should be noted that the dominant condition of modern development of countries and people are the information society, where the dynamism, rapidity, permanence of improvement, speed of implementation of information and communication component in all spheres of life of states and people require virtualization of a significant part of public relations is actively developing, which has also been accelerated by the COVID-19 epidemic, such as public online services, e-commerce, distance learning, etc. It is also important to note that cross-border information flows have intensified, various methods and means of information exchange have spread, being almost uncontrolled by the state. Under these conditions, new information stressors become widespread, which requires states to respond immediately and come up with non-standard measures and solutions. In this regard, information security is becoming a priority issue of the "agenda" at the international, regional and national levels (Zaporozhets, 2009).

There are several important features of modern globalization: developing in all directions, it is multifaceted, interfering in the economies of countries as well as in cultural, scientific, social development, etc.; it strengthens the influence of various actors (including international organizations), redistributing roles and functions in global political relations; provokes the growth of imbalances, heterogeneity, gaps in economic 
GÉNERO E

INTERDISCIPLINARIDADE
Vol n 02 | nº 01 | ISSN: 2675-7451

https://www.periodicojs.com.br/index.php/gei/index development. Globalization at different levels covers different countries, benefits minorities, and even means difficult transformations for most countries, pushing them to the periphery. Such skew provokes conflicts and exacerbates inequalities and social problems. The process of globalization is blurring the borders of countries on the one hand and provokes countries to defend their right to self-recognition, the creation of their state on the other. Also, during this period, parallel opposites develop: fragmentation and globalization, regionalization and integration, which requires modern states to be ready and flexible to adapt to modern rapidly changing realities. Often, states simply do not keep up with such dynamics of globalization.

Given the trends in recent years, the development of the EU is beginning to manifest a systemic crisis, which has been affected by a number of large-scale problems, in particular the global financial crisis and migration, terrorist threats, security challenges in the Eastern European region in connection with the aggression of the Russian Federation and so on. Braking of the institutional processes and the impossibility of further integration makes the leading EU states look for opportunities to overcome the crisis and develop a new global strategy that would effectively respond to the challenges that constantly arise in a globalized world (Martyniuk, 2018; Prystaiko, 2019). Well-known global tendencies have a strong impact on Ukraine's development, transforming internal and external policies, social sphere, the economy and security, affecting the dynamics. Modern threats evolve with incredible speed. Therefore, the reaction should be appropriate. Ukraine has a unique experience; 5 years of continuous hybrid attacks considerably strengthened our "immunity". However, for resilience not to remain spontaneous and reactive, we need to create a forward-looking security system at the strategic level (KlympushTsyntsadze, 2019).

\section{DISCUSSION}

On background of development, constant updating and complication of stressors, the main task of the state and public administration (hereinafter - PA) is to find new adequate mechanisms to overcome the consequences and prevent stressors, on the other hand - the formation of new directions of 
development. The diversity and contradictions of modern stressors and the current situation determine the consideration of ways to overcome the above problems, necessarily through the prism of national interests. The Doctrine of Balanced Development "Ukraine 2030" states that the old paradigm of public administration is a key factor hindering development, and the main mistake is the attempt to implement reforms within the old paradigm without radical changes in models of economic development and governance. The key task is effective response and preventive measures for integrated risks (Ukraine $2030 \ldots, 2017)$. This confirms the need to develop and implement a new effective paradigm - the NR paradigm.

Currently, Ukraine is undergoing PA reform, which continues in the context of political and economic crises, military aggression by the Russian Federation in eastern Ukraine, and annexation of Crimea. In addition, there are certain consequences caused by modern globalization processes that affect the state and development of PA. These include: 1. multilevel governance, as global governance is conducted at the international, regional, international and national levels; 2. multi-facetedness, when involving not only national and formal international institutions, but also non-governmental organizations, transnational corporations, informal groups of influence and other stakeholders; 3. De jure multipolarity and de facto unipolarity, when global governance is based on the statements of various governments and international institutions, but in practice, expressing a desire to take into account the interests of the majority of the world community, representatives of global institutions often make the right decisions. Especially considering that they are funded by the richest countries in the world (Bilynska, 2019b).

Modern realities and the state of development of Ukraine are complicated and affect the content and adequacy of governance processes in the state, which should correspond to the existing, negative and positive components of it. Modernization and development of institutes, mechanisms and models of public administration is an actual scientific and practical problem in the world, for transition countries, in particular for Ukraine (Obolensky, 2014). The basic negative components of Ukrainian realities and the risks of sustainable development of the country 
in recent years were the dragging of all the transformational processes leading to the devastating state of most state systems, the complication of living conditions of people and the deterioration of the socio-demoeconomic situation, the scale of the systemic crisis of statehood, which led to massive civil conflicts, aggression, revolutions, complicated by the annexation of the Crimea, full-fledged military events in the East of Ukraine, the formation of separatist sentiments etc. The main negative transformations in Ukraine related to the polyetiological influence of risks in the last years include:

- imperfect infrastructures, economic imbalances and instability;

- discoordinated policies, disparate decisions and practices;

- inconsistency in the adoption and inefficient implementation of management decisions, overloading the economic and socio-humanitarian spheres;

- the failure of many industries / spheres of the state's life, as a result of many years of prolonged, redirected incomplete reforms;

- complex demographic situation and ageing of the population, deterioration of health indicators and, accordingly, reproduction;

- the impoverishment of the population and the growth of social imbalances;

- the growth of emigration of the intellectual and labour potential of the country (Korolchuk, 2019).

All this is aggravated by the conduct of hostilities in the east of the country, the operation of the Combined forces, which in turn leads to:

- the constant growth of the forced migration movement of the population and the emergence of two new social groups: internally displaced persons and participants in hostilities;

- destruction of infrastructure and territories;

- the emergence of new problems with the health of Ukrainians, associated both with battle wounds and with mental health problems, both of the combatants and people staying temporarily or permanently in the zone of operations of the Combined forces;

- increase in the number of abuses and dependencies on alcohol, drugs, antisocial behaviour;

- the intensity of the social climate, the aggression of society, etc. This complicates the processes of 
governance, shapes the vulnerability of the state and the nation, reducing the potential for resilience to risks. Positive shifts in recent years have been:

- a new position of Ukraine as a geopolitical partner (for the first time in its newest history) - Ukraine has received significant support from the world community, influencing the world;

- accession to the EU - European choice that activates the Europeanization of society and the state, systematic renewal of values, assimilation and implementation of European norms and standards of living, introduction of European norms and standards of state administration and local selfgovernment, first of all, via adaptation of the legal framework to the European legal paradigm, an increase in European political and expert assistance;

- a real movement towards the implementation and completion of the necessary reforms;

- systemic reforms, about 60 of them, the realization of which defines the future and the positive results of which can only appear for citizens of Ukraine after years (Korolchuk, 2019).

Public administration has become deformed and extremely ineffective. The main problems of public administration that had to be solved during the transition to public administration in Ukraine, but still remain relevant, include:

- contradictions between the advantages and disadvantages of decentralization, caused by the growing popularity of democratic principles of governance;

- aggravation of issues related to the freedom of the individual, protection and strengthening of his rights, and, at the same time, the restriction of his rights and freedoms by generally recognized and accepted rules;

- providing management in Ukraine in accordance with the requests of citizens and increasing of the participation of citizens in solving economic, political, cultural and other issues, development of self-governance and comanagement;

- ensuring the activity of the process of entering Ukrainian society into the information era, where the role of information and telecommunications has increased, network structures have arisen, a virtual world exists and evolves, which inevitably affects reality with the formation of e-government and selfgovernment, e-democracy, network 
management structures, national intelligence, expert communities etc.;

- resolving issues related to the development of effective crisis management technologies, forecasting and preventing crises, developing anticrisis systems will help stabilize the volatility of social development and strengthening dynamics, scaling up crises, their globalization;

- the difficult problem of disastrously lacking resources - the need to develop a well-balanced, scientifically grounded, resource policy based on the principles of total rescue savings and the introduction of alternative resources with the restructuring of social infrastructure and industry; effectiveness of use under public control; formation of a new resource culture of Ukrainians managers and citizens; active use of resource co-operation, public-private partnership; the prevalence of the use of "resourceless" social management, through the use of works for public benefit, volunteer activities, patronage, etc.;

- corruption of authorities and officials, bureaucratization, low efficiency of management decisions and management culture (Korolchuk, 2019). Ukrainian society is democratizing, moving towards an efficient economy, a highly educated population, political, economic, demosocial stability and development. Such modernization is an evolutionary change of social spheres of state activity (economic, social, political, sociocultural, etc.) to solve problems and contradictions of society. Today, the CS, the public sphere, many components of the political system are not yet fully formed, so public policy is becoming the only speaker of the common interests of all segments of society, aimed at realizing the values of society and achieving the goals of the state. There was an urgent need for radical changes in public administration, local selfgovernment, civil society, national security, training and education of people, etc. There is a great lack of correct scientific developments in the concepts and programs of state development in Ukraine (Korolchuk, 2019).

The urgency of the organization of PA in emergencies in the context of national security in Ukraine is beyond doubt. Especially if we take into account 
that the response to emergencies today does not fully ensure the appropriate level and quality of organization and implementation of effective measures to combat existing threats. Disadvantages include poor operational decisions, untimely and inadequate implementation of emergency response measures and other urgent work, as a result inadequate level of public safety. According to the analysis of data on the state of man-made and natural security in Ukraine (Analytical review..., 2017), among the main problems of the system of response to risks, threats are: lack of effective management; delay in the deployment of the necessary forces and means in the event of an emergency; unsatisfactory interaction between government agencies; low level of logistics, etc. The reasons for such failures of the management system, in most cases, are the lack of appropriate knowledge, experience and practice to respond to the rapid development of a dangerous event, as well as the conditions of imminent threat to life or health. Most often, such circumstances are inherent in man-made disasters, the number of which is $30 \%$ of emergencies in Ukraine, and the number of deaths about 80\% (Analytical review..., 2017).
One of the main ways to solve existing problems is to improve the management system at the state level, creating a single system of preparation and prevention of risks, threats at all levels - this is part of the concept of formation and development of NR - and a single governing body to ensure adequate response to occurring emergencies.

Resilience of the country, its efficiency, its institutional stability provides for the development of public principles in governing the state and society, real guarantee of democratic realization of human rights and freedoms, its needs and interests, trust of citizens to government institutions, perception of power as a leader, capable of forming and implementing strategy of state and social development. The crisis period of state development is a loud signal for audit and transformation of all social institutions, revision and clear definition of necessary strategic priorities of state development, improvement of system and creation of new principles of management, with obligatory revision of value system, formation of new paradigm for effective development of social and political institutions, a combination of state, public and private interests and efforts, 
providing the necessary mechanisms to guarantee the realization of human rights and freedoms.

Modern Ukraine is in a period of transformation, adapting to the demands and aspirations of a society that acquires citizenship, creating modern mechanisms for the formation and implementation of new public values, interactions and new coordination links the basis for important political and administrative decisions. We emphasize that the main component of the formation of an effective state is its socio-cultural qualities - the principles of spirituality, morality and values, guarantee and realization of freedoms, justice, protection and defense of the public interest and more. According to V.V. Holub (2019), the basis for the development of an effective state is the formation of a paradigm of common interests of state and society, protection of natural and civil human rights and freedoms, with emphasis in state policy and strategy on the development of civic initiatives - which is a condition of its stability and efficiency. a guarantee of national security, resistance to internal and external challenges.

The way to improve PA in the current crisis in Ukraine, also due to military-political factors, involves the introduction of alternative best world experience - analyzed, generalized, adapted to national realities. We are convinced that the implementation of the concept of NR is a way to form a resilient state, increase the efficiency of stress management, crisis prevention, development of competitiveness, defense and integrity of the nation is the best alternative today. Radical changes related to the Revolution of Dignity and the course of European integration make it possible to build a new Ukraine on the principles of sustainable development, rule of law, protection of human rights, democracy, solidarity, and good governance (Project-2017..., 2017).

Such development involves: overcoming imbalances in the economic, social and environmental spheres; building a peaceful and secure, socially cohesive society with good governance and inclusive institutions; ensuring partnership of public authorities, local governments, business, science, education and civil society organizations; full employment; high level of science, education and health care; maintaining the environment in a proper state that will ensure the quality of life and well-being of present and 
future generations; decentralization and implementation of regional policy, which provides for a harmonious combination of national and regional interests; preservation of national cultural values and traditions (Schur, 2019). Scholars and practitioners are convinced that a resident state can withstand modern stressors and ensure this development.

We support the view that today state institutions should be oriented to function for the preservation and development of social values, ensuring the security of society. However, it should be remembered that the gap between the expectations of the pop ulation and the real achievements of the government will grow, and the democratic society of Ukraine will not take it for granted, so in implementing reforms and the effectiveness of this management take into account that "the concept of sustainable public administration should be considered synonymous with the concept of safe development, and the effectiveness of this management is crucial as a prerequisite for ensuring the stability of the state and preventing the risks of its destruction" (Orel, 2018).

The formation of the concept of providing NR in Ukraine is an alternative way to modernize security strategies in various spheres of state life. It should also be noted that modern Ukraine is a soil and laboratory for the active development and application of innovative ideas and practices that lay a modern solid foundation for a public approach to the formation of the People's Republic, with emphasis on democracy, constitutional order and Ukrainian values. NR is seen as a multidimensional concept that reflects the concept of comprehensive security: from its political, social and cognitive aspects to economic, cyber and physical security. It should be noted that the concept of NR is considered and interpreted in the works of Ukrainian researchers and scholars as "national security" and "national sustainability", so we will consider scientific publications with these definitions. Today there is still no single interpretation of the concept of NR, but most publications include economic, military, political, environmental, sociohumanitarian aspects of the life of states 
and, on the other hand, consider the human potential to define this term.

It should be noted that in Ukraine, research on this issue has begun recently and is not conducted on a large scale. Among the domestic researchers we can name A. Boyko (2014a; 2014b; 2017), M. Orel (2018), O. Reznikova (2018a; 2018b; 2018c; 2019a; 2019b; 2020), M. Bilynska (2019a; 2019b), O. Korolchuk (2019), Ya. Cherniatevych (2019), etc., who consider the formation of NR through the prism of the stability of the state in various spheres of its life. In the domestic scientific space M.M. Bilynska and O.L. Korolchuk (2018a; 2018b) for the first time proposed to define NR as the ability of the social system to build a normal, full life in difficult conditions, the ability of society to withstand challenges and crises in various spheres of public life by making changes and adapting without harm for the basic values of society and institutions. At the same time, they note that "NR is also an element of society's ability to strengthen national security, and cannot be limited by military, economic or medicalpsychological aspects". Other researchers suggest the integration of NR factors at the micro level, consisting of psychological and political ideas, the perception of individuals to define the term. Such an analysis adds an important component of public participation - a key element in democracies (Kulhinskyi, 2016).

Given the current complex and turbulent conditions of external and internal stressors, crucial are the issue of optimizing the humanitarian sphere and the formation of effective modern measures to ensure the security of updated policies for the development of culture, religion, language, educational, scientific, historical, partial and information support (Pyrozhenko, 2005). We emphasize that an important aspect of this policy is the creation of a modern system of measures to protect human and civil rights and freedoms, because, in organizational and functional terms, humanitarian policy should contribute to the formation of national identity, support and promotion of national culture and language. The relevance of this thesis is confirmed by global transformations, the formation of a new management paradigm and a significant increase in the weight of human resources. It is generally recognized that strengthening the security of Ukraine is the unity of the people around the values of public and private life. Today's and 
previous scientific research of society management, which is based on ensuring the interests of man, determine the objective need to introduce, proven in the world and time, the foundations of society management (Obolensky, 2014).

In modern conditions of development of Ukrainian society, in the presence of economic and political crisis in the country, with a significant impact of globalization and European integration, the problem of preserving the spiritual, religious, cultural and civic self-identification of the Ukrainian people is actualized (Shevchenko and Pelykh, 2015). The "Ukraine 2030" doctrine is clarifying the tasks for balanced prospective development, proposes a new socially oriented model of economic development, where the highest value is the person, and the main driving force of development is the realization of the nation's creative potential (Ukraine 2030.., 2017). These values are meaningful sources of human existence, the basis of the mechanism of self-organization of social security, the factor and leading criteria of sociopolitical stability and sustainable development of the state - the primary sources of formation and development of NR.

In today's security environment, states and societies must be resilient to a variety of stressors and shocks in order to successfully overcome difficulties and remain functional in the face of pressures and transformations. Progress is possible today only under the condition of conscious responsibility for one's own actions at all levels - from the top leadership of the state to each of its citizens, which, in fact, is an important and necessary element in the development of the NR. Ukraine is an independent state that has all the prerequisites to be among the best countries in the world. However, numerous analyzes show that in almost all spheres of public life (political, religious, economic, social, etc.) there are contradictions, conflicts, shortcomings and gaps that are difficult to resolve. In recent years, in order to solve social problems, given the hybridity of threats from the Russian Federation, civil society (hereinafter CS), which is developing in Ukraine, has intensified.

It is well known that a stable society is impossible without the CS. Ukraine provides an ideal example for 
studying the role played by the CS in the implementation of national stability, and thus in ensuring security (Global trends..., 2017) and resilience of the country and the nation. The war in eastern Ukraine has shown that Ukrainian society is not only a consumer of security, but also an active participant in its preservation and strengthening under stress, especially threats to the independence of the state. According to the results of many studies, including O.L. Korolchuk (2019), most threats to Ukraine's national security have an internal origin - corruption, economic crime, environmental and man-made problems, poor cooperation of the authorities with the public, civil society organizations, etc. According to experts, the current level of involvement of the CS potential in creating an effective system of national security and defense in the country today is still insufficient (Law of Ukraine..., 1991; Using the potential..., 2016).

It is generally accepted that the development, activity, effectiveness and strength of the CS is an important component and guarantee of democracy, a reliable wall against authoritarianism and a factor in the security of democratic countries. Accordingly, CS is an important component of NR formation. This thesis becomes even more relevant in today's complex, ambiguous and unpredictable hybrid threats. It should also be noted that public opinion is a good guide for understanding the problems and needs of security and resilience, and opportunities to meet them by both the state and the CS, NGOs or their joint efforts. The Constitution of Ukraine (Article 17) emphasizes that "the protection of the sovereignty and territorial integrity of Ukraine, ensuring its economic and information security are the most important functions of the state" and "the business of the entire Ukrainian people" (Constitution of Ukraine, 1996). It should be noted that the development of CS in Ukraine gained activity after the Maidan in 2014 through volunteer support for defense against external aggression, monitoring the actions of the authorities, adoption and implementation of state decisions in a number of reforms and anti-corruption (Yablonskyi et al., 2017). But the dynamics of sociological research in Ukraine indicates a relatively small number of really active citizens and their associations.

Some researchers state that according to a survey of the population 
of Ukraine, the Revolution of Dignity has not caused radical and systemic changes in social relations in Ukraine. Excessive expectations of society, slow reform, military aggression of the neighboring state and other factors created a frustrating effect - so thought $85.4 \%$ of Ukrainians in 2016 , the main factors of negative assessment were: lack of positive changes in the economy, in the fight against corruption, in conducting reforms; the merging of power and business and the invariability of the ruling elite; incomplete lustration processes; slow integration of Ukraine into the EU (Yablonskyi et al., 2017). Other researchers focus on such problems of CS development in Ukraine as: revealing the radicalization of public protests; hybrid verification of quasicivic activity, manipulation of public activity and democratic participation for the purposes of political struggle; examining legislative initiatives for any obscure and anti-corruption organizations that try to use the circle of NGOs; radicalization of public consciousness and public activity, created with military activity in Ukraine, purchase of Crimea, participation in civil actions in military actions; in addition the deficit of reform, which provided answers to the reduction of public challenges (Yablonskyi et al., 2018). It is already known today that it informs people that the weakening of the acute phase of the crisis may block the CS with a fundamental element of national security and inadequate commandant of the public during the development of NR on ineffective issues and criticism that requires use.

Interesting results of the research of the Ilko Kucheriv Foundation for Democratic Initiatives and the Razumkov Center on public activity, the functioning of NGOs and the formation of CS in Ukraine: a small part of citizens are involved in active civic activities 8$10 \%$; the number of those who volunteered increased: from 12\% (2013) to $18 \%$ (2018) and those who provide financial or material assistance to specific people or organizations - from 29\% in 2012 to $47 \%$ in 2015 and in 2018 - 38.5\% (Charity and volunteering2016..., 2017). The data are similar in the 2016 study - monitoring of volunteer activity showed $14 \%$ of the population, fairly stable and regularly involved in volunteering; NGOs are trusted by $60 \%$ of society. However, there are no manifestations of personal activity of citizens in solving social problems - only 
$6.6 \%$ of respondents are involved in volunteer, public or charitable activities, $87.1 \%$ - denied their participation in such activities. At the same time, awareness of local NGOs increased by only 4\% (Yablonskyi et al., 2018). Citizes believe that security is mainly the implementation of public oversight of public authorities (45\% of respondents), work with youth and socially vulnerable groups (34\%) and the provision of social, psychological and legal assistance to vulnerable groups (24\%) (The level of trust..., 2019).

Surveys in recent years have shown that Ukrainians have a positive attitude to CS, NGOs and community and volunteer activities - NGOs always have a positive rating of trust: $50 \%$ of respondents believe that NGOs are needed in their cities and villages, 65\% approve of the Verkhovna Rada a large number of public activists were involved, $77 \%$ - believe that the state should promote the development of the CS (Civil society in Ukraine..., 2019). Recent researches on civic activity are already linked to the pandemic and forced quarantine and crisis in the world and in Ukraine: the outbreak of the epidemic had some impact on civic activity, showed people their capabilities and strength, increased "social capital" in society - human rights. languages, solidarity, mutual trust and helped to develop skills and technologies of selforganization (half of respondents $(50 \%)$ believe so). Also, $25 \%$ of respondents agree that during the coronavirus pandemic, new social movements, organizations and new leaders emerged, and $70 \%$ - consider partnership in joint activities as a basis in relations between the CS and the state during the crisis; $50 \%$ of respondents see new opportunities for community development during the COVID-19 pandemic, including cooperation with the latest technologies and remote formats, assistance to vulnerable groups and counseling, as well as the fight against fakes, etc. (Civil society in times..., 2020).

The concept of NR envisages the formation of a relationship of trust and cooperation between public authorities and CS, joint efforts and synergistic influence on solving problems - hybrid threats, and the lack of mutual awareness and respect becomes a significant obstacle to achieving this. The gaps between the state and the CS, whose organizations are trusted by the population more than the authorities 
inherent in modern Ukraine, are

adherence to modern European detrimental to national security and, consequently, to the development of the NR. In the study, such problem gaps were shown (Teperik et al..., 2018):

1. The gap in values, which causes a gap in the goals of public authorities and public organizations, which is complicated by the current "fluidity" of goals, due to the permanence of reforms, decentralization, changes in functions and tasks, needs, internal processes, etc. As a result, the civil service bodies have become unable to adequately respond to circumstances and meet the needs of an active, flexible, easily adapted to the requirements of the new realities of the CS. Accordingly, coherence of actions and synergies between the cooperation of the authorities and the CS has not been achieved.

2. Motivation gap: civil society activists are disappointed with the lack of active and effective dialogue and cooperation with public authorities at all levels, unresolved corruption, slow reforms and their ineffectiveness, lack of transparency and openness, and so on.

3. Communication gap: CS representatives, as a national rapid response force and as a source of resilience to hybrid threats, require 
to implement this Strategy (Yablonskyi et al., 2018).

The Law of Ukraine stipulates that the development of the HS is one of the fundamental national interests of Ukraine (Law of Ukraine..., 2018), which has its own impact on the formation of stability and stability of the state. According to N.V. Bartosh (2019), countering hybrid threats, which must be clearly identified, requires attention to increasing the resilience of society and cooperation between the state and the $\mathrm{CS}$; CS is an integral part of the overall stress management system. Constant dynamic modernization of the mechanism of interaction between the $\mathrm{CS}$ and state structures is a strategic priority for modern states, including Ukraine. Let us emphasize again that ensuring the $\mathrm{CP}$, as well as the national security of the country, is the activity of public authorities, citizens and society in general to ensure the strength of their own ability to withstand new stressors. According to O. Vlasyuk (2016), insufficient stimulating and coordinating role of the state in cooperation with NGOs and think tanks results in underdeveloped horizontal relations between public and state organizations, which is due to the legislative unregulated interaction of NGOs with state institutions. Experts consider today the most effective forms of interaction of public organizations with public authorities are expert and scientificpractical measures, joint research, development of conceptual and doctrinal documents on national security (Krupnyk, 2019).

Ukraine has already taken the first steps for social and spiritual unification, demonstrating unity of opinion on the importance of forming an influential CS. However, this does not mean automatic accession to developed countries. The National Strategy for Promotion of CSO Development in Ukraine for 2016-2020 emphasizes: "Interaction of public authorities, local governments with the public remains ineffective due to insufficient transparency of these bodies and bureaucratic procedures for such interaction, low level of mutual trust" (National strategy..., 2016), so the issue does not lose its relevance. There are many works in the scientific literature that in one way or another emphasize the importance of creating a basic foundation for the development of society. As noted by the famous sociologist N.V. Panin, the development of CS involves the construction of a 
basic basis for its improvement (Yevdokymova, 2019).

New challenges to the development of the Ukrainian state are transforming Ukraine to create a highquality real state of affairs, which should play a special role in ensuring national security. One of the important obstacles to success, researchers identify "lobbying their own activities, organizing paid pseudo-protests of interested political actors who, taking advantage of the positive level of trust in NGOs by citizens of Ukraine, use public activities" (Yablonskyi et al., 2018); also, the development of the HS in Ukraine is hampered by the improper attitude of the authorities to public opinion as a full-fledged social institution of public control; weak level of institutional support of public organizations by public authorities; underdeveloped legal framework, etc.

Today, 30 years of Ukraine's independence have brought society back to the point of bifurcation and uncertainty. It is generally accepted that social capital is earned over centuries, at best, decades. Societies that develop their own capacity and efficiency must set goals aimed at increasing social capital, and most importantly - do not deviate from the chosen course. Is Ukrainian society able to overcome difficulties? According to a survey of Ukrainian citizens in 2018 on people's basic feelings about the future of Ukraine, the population feels: hope $(52 \%)$, anxiety (33\%), optimism (28\%) (Results of 2018..., 2018). Thus, the real CS in Ukraine, as a factor of national security, must develop, for which it is necessary to develop quality public administration mechanisms, effective tools and measures (author), the comprehensive application of which will involve systematic measures to implement the idea of a real and powerful CS in Ukraine (Voronko, 2019).

The results of the report of the study on the development of Ukraine's resilience during 2016-2018 "Sustainable Ukraine: support for the strengthening of national resilience and security in Ukraine" are of scientific importance for the development of NR in Ukraine:

- a strong and active CS plays a significant role, is a source of strength, one of the pillars of national security and, accordingly, the NR;

- there is a risk of losing the positive impetus to use the $\mathrm{CS}$ as a basis 
for strengthening the NR, as Ukraine still has a traditional state-oriented understanding of security;

- the role of the CS is taken into account in the implementation of reforms, which is the basis for the implementation of a general (of-society) approach to national security, but does not have a common philosophy, does not have the necessary depth and sequence of actions, as a result - no synergy between state and CS;

- the concept of resilience is not necessarily supported by the state as fundamental to building comprehensive security at the national, regional and local levels. Consolidation, institutionalization and support for the role of the CS face complex challenges.

- the state of Ukraine must continue radical changes in its political, managerial, security and organizational culture, as well as in its society and: 1. recognize the NR as a core concept of national security and understand the principle of its formation "from the bottom up"; 2. clearly define the role of the CS in the development of NR; 3. create effective platforms for attracting NGOs, develop tools to increase its role in addressing the issues and needs of the countrPy; 4. to ensure transparency and openness of governance for the CS, to promote mutual understanding between them, etc. (Teperik et al., 2018).

The key concept of the study - NR - is defined as the ability of a nation to regenerate, adapt, function and develop positively in conditions of intense negative impact of stressors or crisis. According to the authors of this article, NR should be considered in two different directions:

1. As an indicator of society's ability to meet challenges with its intact values and institutions.

2. As progress, moving forward through overcoming the crisis to a new stage of development of society based on behavioral adaptation.

NR is formed as a response to threats to social development through the formation of new political and social relations that characterize the country's ability to overcome crises and conflicts. Such relations are measurable indicators of patriotism, optimism, social integration and political trust. HP is also an element of society's ability to strengthen national security, and cannot be limited by military, economic, or medical-psychological aspects. The concept of NR should be extended to include political and psychological 
components. In a democratic society, aspects such as trust in government and public institutions, patriotism and tolerance play an important role in political participation and social capital, which in turn leads to higher levels of NR (Law of Ukraine..., 2003b; Bilynska and Korolchuk, 2018a).

We also agree with the statements about the importance of clearly defining and outlining the expediency and limits of the use of the term NR, the possibility of replacing the term "national stability" for Ukrainian scientific thought. We are convinced that the concept of NR development contains a broader and more important element - the possibility of prospective fruitful development under any conditions and circumstances for the well-being and development of future generations. At the same time, it should be noted that most studies of domestic scientists are not systemic in nature, are in the initial stages of scientific research and require further research and development. That is why we believe that systematic research on the concept of "NR" can bring domestic scientific thought to a qualitatively new level of understanding of social processes, ensuring the development of statehood, protection of state interests in the international arena.

\section{CONCLUSIONS}

Today Ukraine is challenged by the negative impact of many well-known external (globalization, information, terrorism and war, etc.) and internal (political-legal, social, etc.) and unknown, constantly updated stressors threats, which are characterized by unprecedented, frequent, integrated effects, hybridity, a combination of turbulence and impact. This requires setting up a system of monitoring, prospective analyses and development of modern effective prevention and control methods that can be achieved with the implementation of the development strategy of NR in Ukraine. The consolidation of national progress and application of the comprehensive approach in public management, activation of the CS role in the development of sustainability and security of states require the convergence of the CS and of a state at all levels, establishing rapport and trust, effective use of collaborative efforts, strengths and opportunities. This will significantly increase the openness, flexibility, efficiency, constructiveness 
and efficiency of the ongoing dialogue in order to ensure the synergy of actions and exchange of knowledge, stimulate the awareness of all interested actors. In turn, there are opportunities to develop a common understanding and vision of the strategies, tactics and effective tools for response, creating trusting relationships between the state and the organizations of CS.

To resolve the issues and gaps of modern development and the life of the state associated with the peculiarities of national development, politicaleconomic, socio-humanitarian issues influenced by external and internal stressors, it is necessary to review past strategies, concepts, development plans, replacing them with modern unified strategy targeted at prospective development of the country and nation, which, we believe, is the development strategy of NR. With this purpose, it is necessary to develop a unified concept of NR that is efficient, effective, modern and appropriate for the national realities. Thus, it can be applied in all policies of the state embodied in all spheres of its activity. One of the main tasks will be to ensure the well-being and safety of the country and nation and the formation of a fruitful environment for the development of future generations.

The analysis of scientific sources in this article allows to conclude that NR today is treated as "national stability", the "national security" by Ukrainian researchers. There is no consensus about this definition, but there is an understanding that NR is a complex, multifactorial, multi-faceted concept used in different areas with different meanings; the concept allows people to adapt to unpredictable influences of stressors to function smoothly even in crisis, to preserve the integrity and unity of society. These are covered in the proposed definition. This concept is not innovative, but it is able to provide a single strategy, principles, tools, resources most relevant to the development needs of the country today and in the future. This approach is able to provide maximum results the implementation of state policy in all spheres of its activity and to determine the authentic path of the country, often under unusual, turbulent, difficult conditions of the modern reality.

The existing problems of transformation and improvement of public management in Ukraine, the weaknesses and the distortions of the 
development of civil society, existing gaps of social development complicate the path and distance the results that will move the country forward to a high quality of life of the state and the society, stable development, competitiveness and resilience. Therefore, it is necessary to take measures to overcome these difficulties and crises, providing the complete reform of the PM, the stability of functioning and activity of CS and the unification of efforts of all interested actors to receive the benefits of their synergistic activities for the development of Ukraine and the Ukrainian nation (Decree of the President..., 2016). We see the strategy of NR development as a quality solution that is able to ensure unity of purpose, comprehensiveness and timeliness of the measures, efficient use of resources and maximum productivity in all spheres of society and state.

Further research is required for issues: development of the concept, strategy and measures for its implementation and improvement in Ukraine at all levels, as an integrated system of sustainable development of the country and nation, protection from exposure to stressors of modern life; establishment of a system of indicators and important factors of influence that characterize its development. These should be clearly defined, adapted to Ukrainian realities, adequately measured, easily controlled even under the conditions of appearance and development of turbulence due to internal or external stressors and their consequences; establishment of a scientific basis for the formulation and development of the NR culture of the Ukrainian nation, taking into account national peculiarities, as the significant factor ensuring a high level of NR.

In fact, the development, implementation and continuous improvement of the concept of development of NR in Ukraine are seen as a relevant, modern, effective way of prospective strategic development of the country and its administration on all levels, which should be implemented to all development policies of the state. In our opinion, resiliency differs from sustainability in the stored ability of a prospective development in all circumstances, under all conditions to ensure a fruitful future for the descendants - and this is the next question for the definition of further research. 


\section{References}

Analytical review of the state of technogenic and natural security in Ukraine.

2017.

http://www.dsns.gov.ua/files/prognoz/re port/2017/rozdil_6.pdf.

Bartosh N.V. Features of cooperation between the state and civil society in the process of ensuring information security in a hybrid war. In: A.P. 2019. Savkov M.M. Bilynska O.M. Petroie. Institutionalization of Public Law in Ukraine in the Conditions of European Integral and Global Challenges: Proceedings of the Annual AllUkrainian Scientific and Practical Conference with International Participation. Kyiv: NADU, 2019.

Bilynska M. M. Institutionalisation of public administration in Ukraine: scientific and analytical report. Kiyv: NAPA, $2019 b$.

Bilynska M., Korolchuk O. The role of national resilience in public administration reforming. Yearbook of Department "Administration and Management", 2018a, 3, 24-45.

Bilynska M.M. Hlobalizatsiini trendy i zahrozy ta vyklyky yevropeiskoi intehratsii. In: M.M. Bilynska, O.M. Petroie (Eds.), Institutionalisation of public administration in Ukraine: scientific and analytical report. Kyiv: NADU, 2019a.

Bilynska M.M., Kavylin O.A. Conceptual Understanding of National Resilience: the role of Public Administration System from US expirience. Bulletin of the NAPA. Series "Public Administration”, 2019, 4(95), 15-18.

Bilynska M.M., Korolchuk O.L. Public administration: a glossary. Kyiv: NADU, 2018b.

Boyko A. Conceptualization of the stability of the national economy. Bulletin of Kyiv National University of Trade and Economics, 2014a, 1, 5-19.

Boyko A. Ensuring the stability of the national economy. Foreign Trade: Economics, Finance, Law, 2017, 4, 1627.

Boyko A.V. Sustainability of the national economy: theory, methodology, practice. Kyiv: Institute of Economics and Forecasting of the National Academy of Sciences of Ukraine, 2014b. Charity and volunteering-2016: results of a sociological study. 2017. https://dif.org.ua/article/blagodiynist-ivolonterstvo-2016-rezultatisotsiologichnogo-doslidzhennya. Cherniatevych Ya. On the need to develop strategic documents in the field 
GÉNERO E

INTERDISCIPLINARIDADE
Vol n 02 | nº 01 | ISSN: 2675-7451

https://www.periodicojs.com.br/index.php/gei/index of economic security of Ukraine. In: A.P. Savkov, M.M. Bilynska, O.M. Petroie (Eds.), Institutionalization of Public Law in Ukraine in the Conditions of European Integral and Global Challenges: Proceedings of the Annual AllUkrainian Scientific and Practical Conference with International Participation. Kyiv: NADU, 2019.

Chervinskyi A., Shutysh M. Globalization: Ukraine remains semiopen and translucent. Ukraine Business, 2014, 16, 4-5.

Chuprii L.V. State and prospects of development of the humanitarian sphere of Ukraine in the conditions of modern globalization challenges. In: A.P. Savkov M.M. Bilynska O.M. Petroie (Eds.), Institutionalization of Public Law in Ukraine in the Conditions of European Integral and Global Challenges: Proceedings of the Annual AllUkrainian Scientific and Practical Conference with International Participation. Kyiv: NADU, 2019.

Civil society in times of pandemic: how COVID-19 affects civic engagement. 2020.

https://dif.org.ua/article/gromadyanskesuspilstvo-v-period-pandemii-yak-vonavplinula-na-gromadsku-aktivnist.
Civil society in Ukraine: the view of citizens.

2019.

https://dif.org.ua/article/gromadyanskesuspilstvo-v-ukraini-poglyad-

gromadyan.

Constitution of Ukraine. 1996. https://zakon.rada.gov.ua/laws/show/25 4\%D0\%BA/96$\% \mathrm{D} 0 \% \mathrm{~B} 2 \% \mathrm{D} 1 \% 80 \#$ Text.

Consultations with the NATO Expert Group on Building a National Sustainability System have begun. 2019. https://www.kmu.gov.ua/news/rozpocha lisya-konsultaciyi-z-grupoyu-ekspertivnato-iz-rozbudovi-sistemi-nacionalnoyistijkosti

Decree of the President of Ukraine No. $287 / 2015$ "On the decision of the National Security and Defense Council of Ukraine of May 6, 2015 "On the National Security Strategy of Ukraine". 2015.

https://zakon.rada.gov.ua/laws/show/28 7/2015\#Text.

Decree of the President of Ukraine No. 68/2016 "On promoting the development of civil society in Ukraine". 2016.

https://www.president.gov.ua/document s/682016-19805.

Global trends and Key implications thorough 2035. 
GÉNERO E

INTERDISCIPLINARIDADE

https://www.dni.gov/files/documents/ni

c/GT-Full-Report.pdf

Guterres A. 2020. This is, above all, a human crisis that calls for solidarity. https://www.un.org/en/un-coronaviruscommunications-team/above-allhuman-crisis-calls-solidarity.

Havryliuk O. Global risks and tools for their minimization. Bulletin of Taras Shevchenko National University of Kyiv. Economy, 2014, 7, 9-13.

Holub V.V. Effective state and institutional stability as an imperative of national security. In: A.P. Savkov M.M. Bilynska O.M. Petroie (Eds.), Institutionalization of Public Law in Ukraine in the Conditions of European Integral and Global Challenges: Proceedings of the Annual AllUkrainian Scientific and Practical Conference with International Participation. Kyiv: NADU, 2019.

Huta S.S. Foreign experience of public administration in crisis situations caused by military and political factors. In: A.P. Savkov M.M. Bilynska O.M. Petroie (Eds.), Institutionalization of Public Law in Ukraine in the Conditions of European Integral and Global Challenges: Proceedings of the Annual AllUkrainian Scientific and Practical
Vol n 02 | nº 01 | ISSN: 2675-7451

https://www.periodicojs.com.br/index.php/gei/index
Conference with International Participation. Kyiv: NADU, 2019.

Khaminich O.M. Resilience: viability or resilience? Scientific Bulletin of Kherson State University. Series: "Psychological Sciences", 2016, 6(2), 160-165.

Kharytonova O.S. Economic stability of the enterprise as a basis for ensuring its competitiveness: thesis of the $\mathrm{PhD}$ in Economics. Luhansk: Volodymyr Dahl East Ukrainian National University, 2008.

Klympush-Tsyntsadze I. Hybrid threats require a public response. 2019. https://www.kmu.gov.ua/news/gibridnizagrozi-vimagayut-zagalnosuspilnoyividpovidi-ivanna-klimpush-cincadze Korolchuk O. Trends of the public management development in Ukraine. In: R. Iserman M. Dei, O. Rudenko Ya. Tsekhmister V. Lunov (Eds.), Association agreement: Driving integrational changes. Chicago: Accent Graphics Communications, 2019 Krupnyk A. S. Civil society in the national security system of Ukraine. In: A.P. Savkov M.M. Bilynska O.M. Petroie (Eds.), Institutionalization of Public Law in Ukraine in the Conditions of European Integral and Global Challenges: Proceedings of the Annual 
All-Ukrainian Scientific and Practical

Conference with International

Participation. Kyiv: NADU, 2019.

Kuibida V.S., Bilynska M.M., Petroie

O.M. (Eds.). Public administration: a glossary. Kyiv: NADU, 2018.

Kulhinskyi Ye.A. National Stress

Resilience in a Democracy: The

Experience of the United States and Israel for Ukraine. International Scientific Journal, 2016, 6(3), 28-34.

Kyrylov Yu.Ye. The impact of globalization on the development of national economies. Efficient Economy, 2016, 12, 24-42.

Law of Ukraine No. 1932-XII “On

Defense of Ukraine". 1991.

http://zakon3.rada.gov.ua/laws/show/19 $32-12 /$.

Law of Ukraine No. 2469-VIII "On

National Security of Ukraine". 2018. I: https://zakon.rada.gov.ua/laws/show/24

69-19

Law of Ukraine No. 964-IV "On

Fundamentals of National Security of

Ukraine". 2003a.

http://zakon.rada.gov.ua/cgi-

bin/laws/main. cgi?nreg=964-15.

Law of Ukraine No. 975-IV "On

Democratic Civilian Control over the

Military Organization and Law

Enforcement Bodies of the State". 2003b.

http://zakon5.rada.gov.ua/laws/show/97

5-15.

Lipkan V.A. National security of Ukraine. Kyiv: Kondor, 2008.

Magnoni S. How civil society must adapt to survive its greatest challenges. 2018. weforum.org/agenda/2018/04/civilsociety-must-adapt-to-survive-itsgreatest-challenges/

Marhasova V.H. The system of ensuring the stability of the national economy and security: theory, methodology, management practice. Chernihiv: Desna Polihraf, 2014.

Martyniuk V. (Ed.). Hybrid threats to Ukraine and public safety. The experience of the EU and the Eastern Partnership. 2018. https://www.civicsynergy.org.ua/wpcontent/uploads/2018/04/blok_XXIend_0202.pdf.

Masten A.S. Resilience in children threatened by extreme adversity: Frameworks for research, practice, and translational synergy. Development and Psychopathology, 2011, 23(02), 493506.

National Research Council. Building Community Disaster Resilience through Private-Public Collaboration. 2011. https://www.nap.edu/catalog/13028/buil 
GÉNERO E

INTERDISCIPLINARIDADE
Vol n 02 | nº 01 | ISSN: 2675-7451

https://www.periodicojs.com.br/index.php/gei/index ding-community-disaster-resilience-

through-private-public-collaboration.

National Research Council. Disaster

Resilience: A National Imperative. 2012.

https://www.nap.edu/catalog/13457/disa

ster-resilience-a-national-imperative.

National strategy for promoting the development of civil society in Ukraine for

2016-2020.

2016.

https://www.kmu.gov.ua/gromadskosti/

gromadyanske-suspilstvo-i-

vlada/spriyannya-rozvitku-

gromadyanskogo-suspilstva/nacionalna-

strategiya-spriyannya-rozvitku-

gromadyanskogo-suspilstva-v-ukrayinina-2016-2020-roki.

Obolensky A.Yu. Public management: the trend of civilization, scientific theory and field of education. In: V. Kovbasyuk S., Romaniuk A., Obolensky (Eds.), Public administration: routes to development: Materials of a scientificpractical conference with international participation. Kyiv: NAGA, 2014.

Order of the Cabinet of Ministers of Ukraine No. 297-2018-p “On approval of the action plan for 2018 on the implementation of the National Strategy for Civil Society Development in Ukraine for 2016-2020”. 2018. http://zakon2.rada.gov.ua/laws/show/29 7-2018-\%D1\%80
Order of the Ministry of Economic Development and Trade of Ukraine No. v1277731-13 “On approval of Methodical recommendations for calculating the level of economic security of Ukraine". 2013. https://zakon.rada.gov.ua/rada/show/v1 277731-13.

Orel M.H. Dualistic unity of stability and security of the state, approaches to its research and consideration in the formulation and functioning of the system of public administration. Scientific journal of the Academy of National Security, 2018, 3-4, 19-20.

Project-2017: Strategy of sustainable development of Ukraine until 2030. 2017.

https://www.undp.org/content/dam/ukra ine/docs/SDGreports/UNDP_Strategy_v 06-optimized.pdf.

Protasenko K.O. The main directions of improvement of the system of public management of ensuring internal political security of Ukraine. In: A.P. Savkov M.M., Bilynska O.M., Petroie (Eds.), Institutionalization of Public Law in Ukraine in the Conditions of European Integral and Global Challenges: Proceedings of the Annual AllUkrainian Scientific and Practical 
GÉNERO E

INTERDISCIPLINARIDADE
Vol n 02 | nº 01 | ISSN: 2675-7451

https://www.periodicojs.com.br/index.php/gei/index
Conference with International

Participation. Kyiv: NADU, 2019.

Prystaiko V.V. Directions for ensuring Ukraine's military security in the context of globalization challenges. In: A.P. Savkov M.M., Bilynska O.M., Petroie (Eds.), Institutionalization of Public Law in Ukraine in the Conditions of European Integral and Global Challenges: Proceedings of the Annual AllUkrainian Scientific and Practical Conference with International Participation. Kyiv: NADU, 2019.

Pyrozhenko V.O. The humanitarian component of national security: the subject of research and the range of main problems. Strategic Panorama, 2005, 2, 27-35.

Results of 2018: public opinion. 2018. https://dif.org.ua/article/pidsumki-2018gromadska-dumka.

Reznikova O. What exactly are we building up when it comes to national stability? 2019a.

https://www.dt.ua/internal/scho-samemi-rozbudovuyemo-govoryachi-pronacionalnu-stiykist-318005_html

Reznikova O.O. Conceptual approaches to the choice of the model of ensuring national stability. Strategic Priorities, 2019b, 1, 18-27.
Reznikova O.O. Conceptual principles of national stability. State and Law. Political Science, 2018a, 81, 135-146.

Reznikova O.O. Ensuring national security and national stability: common features and differences. Bulletin of Lviv University. Series: "Philosophical and Political Studies", 2018b, 19, 170-175. Reznikova O.O. Features of state policy formation on the principles of national stability. Bulletin of Lviv University. Series: "Philosophical and Political Studies", 2018c, 18, 349-353.

Reznikova O.O. On the Concept of Ensuring National Sustainability in Ukraine. 2020. https://niss.gov.ua/sites/default/files/202 0-01/analit-resnikova-national-security8-2020-1-1.pdf.

Shchur N.O. Vplyv hlobalnykh ryzykiv na suspilnyi rozvytok Ukrainy. In: A.P. Savkov M.M., Bilynska O.M., Petroie (Eds.), Institutionalization of Public Law in Ukraine in the Conditions of European Integral and Global Challenges: Proceedings of the Annual AllUkrainian Scientific and Practical Conference with International Participation. Kyiv: NADU, 2019.

Shevchenko M.M., Pelykh A.O. Methodological approaches to assessing the effectiveness of the state mechanism 
for responding to threats to national interests. Investments: Practice and Experience, 2015, 13-14, 82-86.

Shkuropadska D. Sustainability of the national economy in the context of global challenges. Foreign Trade: Economics, Finance, Law, 2017, 4, 8497.

Shypilova L.M. Methodological approach to the implementation of the policy of national security of Ukraine. In: A.P. Savkov, M.M. Bilynska, O.M. Petroie (Eds.), Institutionalization of Public Law in Ukraine in the Conditions of European Integral and Global Challenges: Proceedings of the Annual All-Ukrainian Scientific and Practical Conference with International Participation. Kyiv: NADU, 2019.

Sokolova L.V., Veriasova G.M., Sokolov O.Y. Scientific and Methodical Support for Enterprise's Competitiveness Increase under Conditions of Marketing Orientation. Slovak International Scientific Journal, 2018, 1(16), 15-17.

Surmin Yu.P. Problems and directions of changes of public administration in Ukraine in modern conditions. In: V. Kovbasyuk S., Romaniuk A., Obolensky (Eds.), Public administration: routes to development: Materials of a scientific- practical conference with international participation. Kyiv: NAGA, 2014.

Teperik D., Yermalavichu Th., Senkiv H., Dubov D., Onyschuk Ye., Pokalchuk O., Samus M. Report: "Sustainable Ukraine: State, Civil Society and National Security”. Tallin: International Centre for Defence and Security, 2018. The level of trust in public institutions and electoral orientations of Ukrainian citizens. 2019. http://razumkov.org.ua/napriamky/sotsi ologichni-doslidzhennia/riven-dovirydo-suspilnykh-instytutiv-ta-elektoralnioriientatsii-gromadian-ukrainy.

The National Security and Defense Council submitted to the President for approval the Strategy of National Security and Defense "Human Security Security of the Country”. 2020. https://www.president.gov.ua/news/rnb o-peredala-na-zatverdzhennyaprezidentu-strategiyu-nacbez-59873.

Ukraine 2030: The Doctrine of Sustainable Development. Lviv: Kalvariia, 2017.

Using the potential of non-state think tanks in shaping national security policy. 2016.

http://www.niss.gov.ua/articles/2119/. 
Vlasiuk O.S. National Security of Ukraine: Evolution of Domestic Policy Problems. Kyiv: NISD, 2016.

Voronko L.O. Real civil society as a factor in ensuring national security: Problems of realization of ideas in Ukraine. In: A.P. Savkov M.M., Bilynska O.M., Petroie (Eds.), Institutionalization of Public Law in Ukraine in the Conditions of European Integral and Global Challenges: Proceedings of the Annual AllUkrainian Scientific and Practical Conference with International Participation. Kyiv: NADU, 2019.

Yablonskyi V.M., Andriuchenko T.V., Bekeshkina I.E. Civil society of Ukraine: modern practices and development challenges. Kyiv: NISD, 2018.

Yablonskyi V.M., Balakirieva O.M., Bondar T.V. On the state of development of civil society in Ukraine. Kyiv: NISD, 2017.

Yevdokymova V.V. Development of civil society as a guarantee of development of the foundations of the state. In: A.P. Savkov, M.M. Bilynska, O.M. Petroie (Eds.), Institutionalization of Public Law in Ukraine in the Conditions of European Integral and Global Challenges: Proceedings of the Annual All-Ukrainian Scientific and
Practical Conference with International Participation. Kyiv: NADU, 2019.

Zaporozhets O.Yu. European Union information security policy. Current Issues of International Relations, 2009, 87(2), 36-45. 